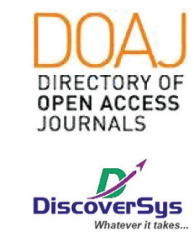

Published by DiscoverSys

\section{Analisis rasio netrofil limfosit dan rasio platelet limfosit terhadap penanda gangguan ginjal pada penyakit systemic lupus erythematosus di RSUP dr. Wahidin Sudirohusodo tahun 2017-2018}

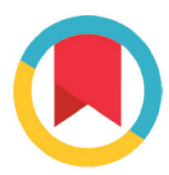

CrossMark

\author{
Evi Andriyani Lauddin ${ }^{1 *}$, Asvin Nurulita², Darwati Muhadi ${ }^{2}$
}

\section{ABSTRACT}

Background: Systemic Lupus Erythematosus (SLE) is an autoimmune disease that causes damage to several organ systems including the kidneys. The neutrophil-lymphocyte ratio (NLR) and the platelet-lymphocyte ratio (PLR) continue to be developed as a marker of SLE disease activity. This study aimed to assess NLR and PLR for markers of kidney disorders in SLE.

Method: A retrospective study evaluated NLR and PLR with routine urine results including proteinuria, hematuria, and casts from 40 subjects of SLE patients at Dr.Wahidin Sudirohusodo Hospital
Makassar from July 2017 - July 2018. Descriptive statistical analysis, frequency distribution and Mann-Whitney statistical test.

Results: NLR values were significantly higher in positive hematuria than negative hematuria, which was 7.44 compared to 3.80 (p $<0.05$ ).

Conclusion: A significant relationship between increased NLR values and hematuria can be used as a marker of early occurrence of lupus nephritis even though no manifestations or signs of other kidney disorders are found.

Keywords: neutrophil-lymphocyte ratio, platelet-lymphocyte ratio, SLE, lupus nephritis

Cite This Article: Lauddin, E.A., Nurulita, A., Muhadi, D. 2019. Analisis rasio netrofil limfosit dan rasio platelet limfosit terhadap penanda gangguan ginjal pada penyakit systemic lupus erythematosus di RSUP dr. Wahidin Sudirohusodo tahun 2017-2018. Intisari Sains Medis 10 (1): 251-255. Dol: 10.1556/ism.v10i1.362

\title{
ABSTRAK
}

${ }^{1}$ Program Studi Pendidikan Dokter Spesialis, Ilmu Patologi Klinik, Fakultas Kedokteran Universitas Hasanuddin/RSUP Dr. Wahidin Sudirohusodo, Makassar, Indonesia ${ }^{2}$ Departemen IImu Patologi Klinik, Fakultas Kedokteran Universitas Hasanuddin/ RSUP Dr. Wahidin Sudirohusodo, Makassar, Indonesia

\section{*Korespondensi :}

Evi Andriyani Lauddin; Program Studi Pendidikan Dokter Spesialis, IImu Patologi Klinik, Fakultas Kedokteran Universitas Hasanuddin/RSUP Dr. Wahidin Sudirohusodo, Makassar, Indonesia;

evi_andriyani@yahoo.co.id

Diterima : 13-11-2018

Disetujui : 22-03-2019

Diterbitkan : 01-04-2019
Latar Belakang: Systemic Lupus Erythematosus (SLE) merupakan penyakit autoimun yang menyebabkan kerusakan pada beberapa sistem organ termasuk ginjal. Rasio netrofil limfosit (RNL) dan rasio platelet limfosit (RPL) terus dikembangkan sebagai penanda aktivitas penyakit SLE. Tujuan penelitian ini untuk menilai RNL dan RPL terhadap penanda gangguan ginjal pada penyakit SLE.

Metode: Penelitian retrospektif menilai RNL dan RPL dengan hasil urin rutin meliputi protein urin, hematuri dan silinder dari 40 subyek pasien SLE di RSUP dr. Wahidin Sudirohusodo Makassar dari bulan Juli 2017 - Juli 2018. Analisis statistik deskriptif, sebaran frekuensi dan uji statistik Mann-Whitney.

Hasil: Nilai RNL signifikan lebih tinggi pada hematuria positif dibandingkan hematuria negatif, yaitu 7,44 dibandingkan 3,80 (p $<0,05)$.

Simpulan: Hubungan yang signifikan antara meningkatnya nilai RNL dengan hematuria dapat dijadikan penanda awal akan terjadinya nefritis lupus walaupun tanpa ditemukan adanya manifestasi atau tanda-tanda gangguan ginjal lainnya.

Kata Kunci: Rasio netrofil limfosit, rasio platelet limfosit, SLE, nefritis lupus

Site Pasal Ini: Lauddin, E.A., Nurulita, A., Muhadi, D. 2019. Analisis rasio netrofil limfosit dan rasio platelet limfosit terhadap penanda gangguan ginjal pada penyakit systemic lupus erythematosus di RSUP dr. Wahidin Sudirohusodo tahun 2017-2018. Intisari Sains Medis 10 (1): 251-255. D0I: 10.1556/ism.v10i1.362

\section{PENDAHULUAN}

Systemic Lupus Erythematosus (SLE) merupakan penyakit autoimun yang menyebabkan kerusakan pada beberapa sistem organ. Manifestasi klinik serta prognosis yang beragam, lebih sering ditemukan pada wanita dan sampai saat ini etiologi penyakit belum diketahui. ${ }^{1,2,3}$
Penyakit SLE dapat terjadi pada masa anak dan dewasa, tetapi $20 \%$ kasus didiagnosis pada anak, tetapi manifestasi dan prognosis yang ditemukan juga lebih buruk jika dibandingkan dengan SLE yang baru terjadi pada usia dewasa. The Lupus Foundation of America memperkirakan sekitar 1,5 juta kasus terjadi di Amerika dan setidaknya 
terjadi lima juta kasus di dunia. Setiap tahun diperkirakan terjadi sekitar 16 ribu kasus baru. ${ }^{4}$

Data rumah sakit pada tahun 2016 diketahui bahwa di Indonesia terdapat 2.166 pasien rawat inap yang didiagnosis penyakit SLE, dengan 550 pasien diantaranya meninggal dunia. Jumlah pasien rawat inap rumah sakit meningkat sejak tahun 20142016. Jumlah kasus SLE tahun 2016 meningkat hampir dua kali lipat dibandingkan tahun 2014, yaitu sebanyak 1.169 kasus. Jumlah kematian akibat SLE pada pasien rawat inap di rumah sakit juga meningkat tinggi dibandingkan dengantahun 2014. Jumlah pasien meninggal akibat SLE pada tahun 2015 (110 kematian) menurun jika dibandingkan tahun 2014. Jumlah ini meningkat drastis pada tahun 2016, yaitu sebanyak 550 kematian. $^{4}$

Diagnosis SLE menggunakan kriteria dari American College of Rheumatology (ACR) 1997 dimana pasien harus memiliki 4 dari 11 klasifikasi kriteria. ANA tes positif dan hanya dijumpai 3 kriteria maka sangat mungkin SLE dan diagnosis bergantung pada pengamatan klinis. ${ }^{3,5}$

Penyakit SLE ditandai dengan aktivasi sel B dan menghasilkan sitokin yang mempunyai peran penting dalam patogenesis dari SLE. Pada penyakit ini dijumpai peningkatan jumlah netrofil dan penurunan jumlah limfosit. Platelet berkaitan dengan respon inflamasi,dimana pada pasien SLE lebih sering ditemukan jumlah trombosit yang menurun. Korelasi yang kuat antara rasio netrofil limfosit (RNL) dan rasio platelet limfosit (RPL) memiliki hubungan dengan sitokin atau penanda inflamasi pada aktivitas SLE yang berat. ${ }^{6}$

Penelitian dari Amaylia et.al menemukan bahwa RNL mengalami peningkatan pada penyakit SLE dibandingkan subjek normal. Baodong et.al menemukan peningkatan dan korelasi positif RNL dengan CRP, ESR dan SLEDAI. Elhafeez et.al dalam penelitiannya menemukan bahwa RNL dan RPL dapat digunakan sebagai penanda diagnostik pada SLE. 2,7

Ginjal merupakan organ penting yang paling sering terkena pada SLE walaupun bukan suatu keadaan yang homogen, terdapat spektrum yang luas baik pada manifestasi klinis maupun kelainan patologis sehingga banyak penjelasan untuk pathogenesis terkenanya ginjal pada SLE. Nefritis dijumpai pada $20-75 \%$ penderita SLE, banyak diantaranya timbul pada tahun pertama setelah diagnosis SLE. Pemeriksaan yang cermat sangat penting oleh karena banyak penderita yang mempunyai kelainan urin asimptomatik, seperti hematuri atau protein urin. ${ }^{8}$

Kriteria ACR 1997 salah satunya adalah ditemukan tanda gangguan ginjal pada pemeriksaan urinalisa berupa protein urin menetap $>0.5$ gram per hari atau $\geq 3+$ bila tidak dilakukan pemeriksaan kuantitatif. Silinder dapat ditemukan berupa silinder eritrosit, hemoglobin, granular,tubular atau campuran. ${ }^{3,5}$

Protein urin menggambarkan luasnya gangguan pada glomerulus dan cenderung meningkat pada kelainan ginjal yang lebih berat. Hematuri glomerular yang diketahui dari eritrosit dismorfik sering dijumpai pada lupus nefritis dan biasanya disertai dengan protein urin. Gambaran sindroma nefritis yang lengkap (hematuri dengan silinder seluler dan protein urin) dijumpai pada $30-40 \%$ penderita, sementara glomerulonefritis yang progresif cepat (kadar serum kreatinin meningkat menjadi dua kali dalam 3 bulan) adalah jarang dan dijumpai pada $10 \%$ awal penyakit. ${ }^{8}$

Penyakit SLE memiliki gambaran klinis yang luasdantampilan perjalanan penyakityangberagam. Penelitian terhadap RNL,RPL dan pemeriksaan urinalisa menggunakan tiga parameter penilaian yaitu protein urin, hematuri, silinder dapat dijadikan penanda adanya gangguan ginjal yang biasanya asimptomatik pada SLE sehingga pasien mendapat perhatian khusus agar tidak terjadi perburukan dari fungsi ginjal dan terapi yang tepat. ${ }^{7}$ Oleh karena itulah penelitian ini bertujuan untuk mengetahui rasio netrofil limfosit dan rasio platelet limfosit terhadap penanda gangguan ginjal pada penyakit SLE.

\section{METODE}

Penelitian ini merupakan penelitian retrospektif menggunakan data pasien dengan diagnosa SLE periode Juli 2017 - Juli 2018 di Instalasi Rekam Medik RSUP dr. Wahidin Sudirohusodo. Sampel penelitian meliputi semua pasien dengan diagnosis SLE yang disertai hasil pemeriksaan darah rutin dan urin rutin. Pasien yang mendapat terapi Cyclophosphamide, Azathioprine atau methotrexate dalam 1 bulan terakhir, Diabetes Mellitus, Coronary Artery Disease, Arthritis dan sepsis dieksklusi dalam penelitian ini.

Parameter yang digunakan dalam penelitian ini meliputi hasil urinalisa (hematuri,protein urin dan silinder) yang dilakukan untuk melihat adanya gangguan ginjal. Nilai RNL yang merupakan perbandingan nilai netrofil absolut dan limfosit absolut, nilai RPL yang merupakan perbandingan trombosit dan limfosit absolut berdasarkan hasil pemeriksaan alat Hematology Analyzer.

\section{HASIL}

Penelitian dilakukan selama 1 tahun terhadap 40 pasien SLE yang telah memenuhi kriteria inklusi dan eksklusi yang berumur antara 10-42 tahun 
Tabel 1. Karakteristik sampel pada pasien SLE

\begin{tabular}{|c|c|c|c|c|}
\hline Parameter & $\mathbf{N}(\%)$ & Rentang & Mean & SD \\
\hline \multicolumn{5}{|l|}{ Jenis Kelamin } \\
\hline Laki-Laki & $1(2,5 \%)$ & & & \\
\hline Perempuan & $39(97,5 \%)$ & & & \\
\hline \multicolumn{5}{|l|}{ Umur } \\
\hline$<20$ tahun & $8(20 \%)$ & & & \\
\hline 20-29 tahun & $21(52,5 \%)$ & & & \\
\hline$\geq 30$ tahun & $11(27,5 \%)$ & & & \\
\hline \multicolumn{5}{|l|}{ Hematuri } \\
\hline Positif & $12(30 \%)$ & & & \\
\hline Negatif & $28(70 \%)$ & & & \\
\hline \multicolumn{5}{|l|}{ Protein urin } \\
\hline Positif & $20(50 \%$ & & & \\
\hline Negatif & $20(50 \%)$ & & & \\
\hline \multicolumn{5}{|l|}{ Silinder } \\
\hline Positif & $15(37,5 \%)$ & & & \\
\hline Negatif & $25(62,5 \%)$ & & & \\
\hline RNL & & $0,75-18,17$ & 4,89 & 4,06 \\
\hline RPL & & $12,80-748,78$ & 207,00 & 167,26 \\
\hline
\end{tabular}

Sumber : Data Sekunder

Tabel 2. Perbandingan RNL dan RPL dengan hematuri

\begin{tabular}{lllccc}
\hline & Hematuria & $\mathbf{n}$ & Mean & SD & p \\
\hline \multirow{2}{*}{ RNL } & Positif & 12 & 7,44 & 5,55 & $0,049^{*}$ \\
& Negatif & 28 & 3,80 & 2,68 & \\
\multirow{2}{*}{ RPL } & Positif & 12 & 243,00 & 201,75 & 0,457 \\
& Negatif & 28 & 191,56 & 151,67 & \\
\hline
\end{tabular}

Mann-Whitney test
Hasil uji statistik yang dilakukan ditemukan perbedaan tersebut tidak signifikan ( $p>0,05)$.

Nilai RNL ditemukan lebih tinggi pada proteinuri positif dibandingkan yang negatif yaitu 5,49 dibandingkan 4,30, namun secara statistik tidak signifikan $(\mathrm{p}>0,05)$. Nilai RPL ditemukan lebih rendah pada proteinuri negatif yaitu 205,07 dibandingkan 208,92 namun secara statistik tidak signifikan $(\mathrm{p}>0,05)$

Nilai RNL ditemukan lebih tinggi pada silinder positif dibandingkan yang negatif, yaitu 5,56 dibandingkan 4,50 namun secara statistik tidak signifikan $(p>0,05)$. Nilai RPL ditemukan lebih rendah pada silinder positif dibandingkan yang negatif yaitu 199,97 dibandingkan 211,21 namun secara statistik tidak signifikan ( $p>0,05)$.

\section{PEMBAHASAN}

Penelitian ini mengambil data rekam medis periode Juli 2017 - Juli 2018. Penelitian ini merupakan penelitian retrospektif pada 40 pasien SLE yang memenuhi kriteria inklusi dan eksklusi. Perempuan lebih banyak menderita SLE dibanding laki-laki dengan rentang umur 20-29 tahun.

Respon fisiologis pada sistem imunitas terhadap inflamasi sistemik adalah peningkatan jumlah netrofil dan penurunan jumlah limfosit, mengakibatkan perubahan dinamika dan regulasi apoptosis pada keadaan inflamasi sistemik bila dibandingkan dengan keadaan non-infalamasi. Metabolik toksik yang dilepaskan netrofil yang teraktivasi dan ditambah dengan sitokin inflamasi akan merusak jaringan serta fungsi organ. ${ }^{9}$

Proses apoptosis limfosit mengakibatkan imunosupresi sistem imunitas adaptif sehingga akan mencetuskan reaksi inflamasi yang lebih lanjut. Meningkatnya jumlah netrofil absolut serta penurunan limfosit absolut akan meningkatkan nilai RNL jika dibandingkan dengan pasien tanpa reaksi inflamasi. Sejalan dengan peningkatan RNL maka risiko morbiditas dan mortalitas pasien yang ditandai dengan kerusakan dan kegagalan fungsi organ akan semakin meningkat. ${ }^{9}$

Platelet memiliki peran besar dalam proses inflamasi dan kekebalan tubuh, pada pasien SLE lebih sering ditemukan jumlah trombosit yang menurun. Jumlah platelet yang dihubungkan dengan jumlah limfosit yang menurun akan menyebabkan nilai RPL meningkat. ${ }^{10}$

Peningkatan nilai RNL dan RPL ini sejalan dengan penelitian Amaylia et.al menemukan bahwa RNL mengalami peningkatan pada penyakit SLE dibandingkan subjek normal. Penelitian Elhafeez et.al juga menemukan terjadinya peningkatan RNL dan RPL pada SLE sehingga dapat dirgunakan sebagai penanda diagnostik. ${ }^{3}$ 


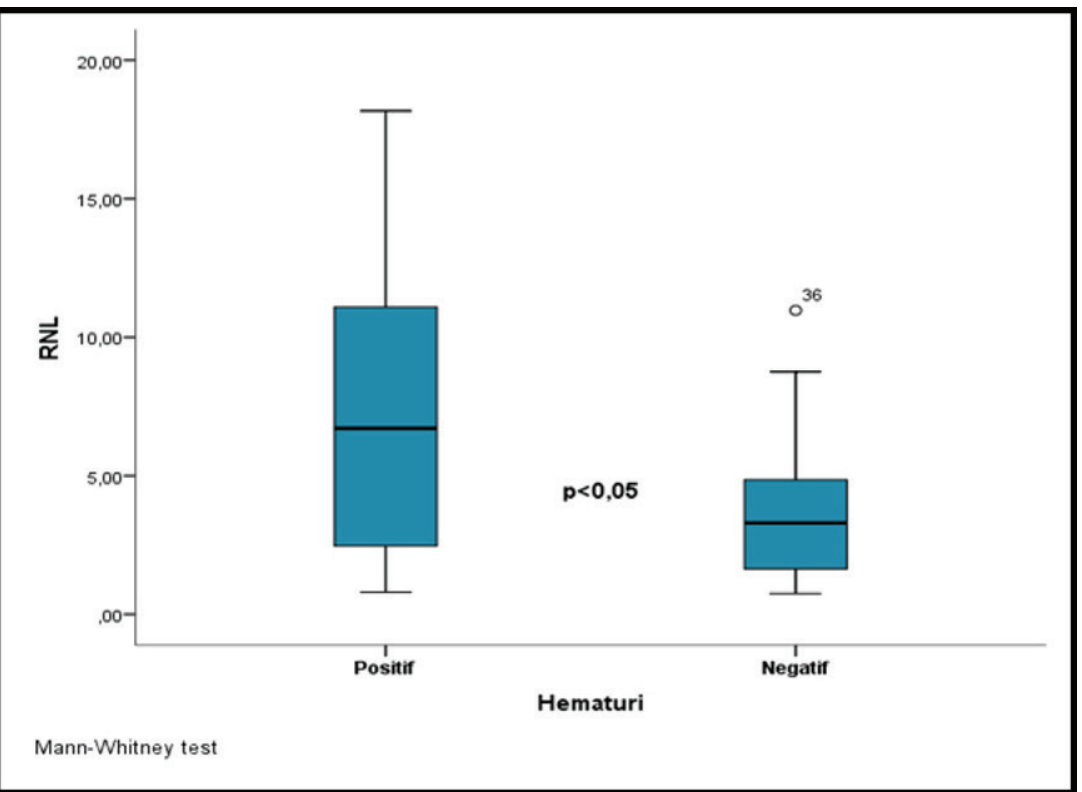

Gambar 1. Perbandingan RNL menurut Hematuri

Tabel 3. Perbandingan RNL dan RPL dengan proteinuri

\begin{tabular}{cccccc}
\hline & Proteinuria & N & Mean & SD & p \\
\hline \multirow{2}{*}{ RNL } & Positif & 20 & 5,49 & 4,99 & 0,871 \\
& Negatif & 20 & 4,30 & 2,86 & \\
& Positif & 20 & 205,07 & 182,29 & 0,665 \\
RPL & Negatif & 20 & 208,92 & 155,53 & \\
\hline
\end{tabular}

Mann-Whitney test

Tabel 4. Perbandingan RNL dan RPL dengan silinder

\begin{tabular}{cccccc}
\hline & Silinder & N & Mean & SD & p \\
\hline \multirow{2}{*}{ RNL } & Positif & 15 & 5,55 & 5,33 & 0,922 \\
& Negatif & 25 & 4,50 & 3,13 & \\
\multirow{2}{*}{ RPL } & Positif & 15 & 199,97 & 196,95 & 0,379 \\
& Negatif & 25 & 211,21 & 150,95 &
\end{tabular}

Mann-Whitney test menyebakan glomerulus akan mengalami inflamasi dan akan kehilangan fungsinya sebagai penyaring secara bertahap, sehingga akan ditemukan banyak sel darah merah yang melewati glomerulus. ${ }^{11}$

Peningkatan RNL menandakan terjadinya proses inflamasi yang dapat menyebabkan kerusakan sistem organ dihubungkan dengan ditemukannya hematuri yang berarti terdapat kerusakan pada glomerulus ginjal dapat dijadikan penanda kemungkinan besar terjadinya lupus nefritis. Sejalan dengan penelitian Akbarian dkk yang menemukan sebagian besar pasien dengan SLE dan hematuri tanpa adanya kerusakan ginjal lain dalam perkembangan nya akan menjadi nefritis lupus dan dilakukan biopsi ginjal.

Nilai RNL dan RPL yang dihubungkan dengan protein urin pada penelitian ini tidak dijumpai hubungan yang signifikan, Protein urin yang terjadi pada pasien SLE menggambarkan kerusakan pada glomerulus, namun protein yang terdeteksi positif bisa saja disebabkan $\mathrm{pH}$ urin yang bersifat sangat alkali $(\mathrm{Ph}>8)$ sehingga bisa terbaca hingga +2 atau bisa saja terdeteksi albumin, bukan protein yang berhubungan dengan protein urin pada tubulus seperti $\beta 2$-microglobulin sehingga menyebabkan tidak adanya hubungan antara peningkatan RNL dan RPL dengan protein yang terdeteksi pada urin. ${ }^{1}$ Silinder yang dikaitkan dengan peningkatan RNL dan RPL juga tidak ditemukan hubungan yang signifikan.

\section{SIMPULAN}

Hubungan yang signifikan antara meningkatnya nilai RNL dengan hematuri dapat dijadikan penanda awal akan terjadinya nefritis lupus walaupun tanpa ditemukan adanya manifestasi atau tanda-tanda gangguan ginjal lainnya. Kerusakan ginjal yang lebih berat dapat dicegah dengan terapi yang tepat.

\section{CONFLICT OF INTEREST}

Tidak ada

\section{DAFTAR PUSTAKA}

1. Robert LG. The Clinical Presentation of Systemic Lupus Erythematosus. Systemic Lupus Erythematosus $5^{\text {th }}$ Edition. UK: Elsevier.2011: 525-526.

2. Abd-Elhafeez HA, El-Meghawry ES, Omran TM, et al. Study of Neutrophil Lymphocyte Ratio and Platelet Lymphocyte Ratio as Inflammatory Markers in Systemic Lupus Erythematosus Egyptian Patients. Electronic Journal of Biology, 2017; 13(3):248-252

3. Oehadian A, Suryadinata H, Dewi S, Pramudyo R, Alisjahbana B.. The Role of Neutrophil Lymphocyte Count Ratio as an Inflammatory Marker in Systemic Lupus Erythematosus. Acta Med Indones. 2013; 45(3):170-4

4. Pusdatin. Situasi Lupus di Indonesia, Infodatin. Pusat Data dan Informasi Kementerian Kesehatan. 2017: 1-2 
5. Uribe AG, Vilá LM, McGwin G Jr, Sanchez ML, Reveille JD, Alarcón GS.. The Systemic Lupus Activity Measurerevised, The Mexican Systemic Lupus Erythematosus Disease Activity Index (SLEDAI), activity in systemic lupus erythematosus. J Rheumatol. 2004; 31(10):1934-40.

6. Lee HY, Song GG. Association of Neutrophil to Lymphocyte Ratio, Platelet to Lymphocyte Ratio, and Mean Platelet Volume with Systemic Lupus Erythematosus Disease Activity: A Meta-Analysis. J Rheum Dis. 2017 Oct;24(5):279-286

7. Khan A, Haider I, Ayub M, Khan S. Mean Platelet Volume (MPV) as an Indicator of Disease Activity and Severity in Lupus. F1000Res. 2017; 6: 126.

8. Kasjmir dkk. Diagnosis dan Pengelolaan Lupus Eritematosus Sistemik. Perhimpunan Reumatologi Indonesia. 2011: 5-7

9. Nugroho Adi, Suwarman, Nawawi AM. Hubungan Antara Rasio Netrofil Limfosit dan skor sequential organ failure
Assessment Pada Pasien yang Dirawat di Ruang Intensive Care Unit. Jurnal Anastesi Perioperatif. 2013; 1 (3):189-196

10. Abd-Elazeem MI, Mohamaed RA. Neutrophil Lymphocyte and Platelet Lymphocyte Ratio in Rheumatoid Arthritis Patients: Relation to Disease Activity. The Egyptian Rheumatologist. 2018; 40(4):227-231

11. Youkang Zhang. Causes and treatment of hematuria in lupus.[internet]. 2013. [cited at 2018 September 16]. Available at http://www.kidneyabc.com/lupus-nephritistreatment

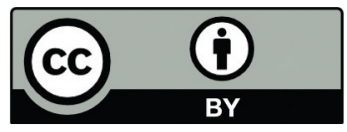

This work is licensed under a Creative Commons Attribution 